\title{
Differences between Effects of Spectral and Fluorescent or Filtered Monochromatic Lights on Inducing Photoperiodic Sensitivity of Pharbitis nil
}

\author{
Michio KoNISHI \\ Laboratory of Applied Botany, Faculty of Agriculture, Kyoto University, Kyoto
}

(Received April 12, 1972)

1) Red light irradiated for a relatively short time to Pharbitis plants grown under continuous green, blue, or far-red lights and in darkness just before a $16 \mathrm{hr}$ dark treatment always initiated flowering induction, but far-red light given in the same way to red light grown plants inhibited flowering induction.

2) The effectiveness of red light given to plants grown under green light before a $16 \mathrm{hr}$ dark treatment to induce photoperiodic sensitivity was compared between fluorescent light obtained from colored fluorescent lamps and spectral light beams from a grating spectrograph.

3) The effectiveness in inhibiting flowering induction of far-red light, obtained through an IR-1 filter and radiant heat cut glass from incandescent lamps, was also compared with that of spectral light beams from the far-red region by irradiating to plants grown under red light for a short time before the dark period.

4) Total energy values required for inducing $100 \%$ flowering by red light were about $37 \times 10^{6} \mathrm{erg} / \mathrm{cm}^{2}$ and $8.9 \times 10^{6} \mathrm{erg} / \mathrm{cm}^{2}$ in fluorescent and spectral light, respectively. Those required for complete inhibition of flowering were $8.6 \times 10^{6} \mathrm{erg} / \mathrm{cm}^{2}$ and $9.9 \times 10^{4}$ in filtered far-red light and spectral light, respectively.

The present experiment indicates that the total energy required for the same photoresponse are apt to be larger in colored fluorescent lights or filtered lights than in spectral light beams. This fact must be considered in photobiological experiments using monochromatic light other than spectral light beams.

5) The regions effective for flowering induction are roughly the three regions with wavelengths of about $550-600 \mathrm{~nm}, 620-640 \mathrm{~nm}$ and $650-675 \mathrm{~nm}$, and those for inhibition of flowering induction range from about $710 \mathrm{~nm}$ to $770 \mathrm{~nm}$.

6) Experimental conditions for light and temperature were examined in detail. Reasons for the difference in total energy values between fluorescent light and spectral light were discussed.

Endogeneous rhythm, the "biological clock", and phytochrome pigments in tide, based on the reversible effects of red and far-red lights on photoperiodic induction, have been reported as the mechanism for inducing photoperiodism in longday and shortday plants. ${ }^{1 \sim 3}$ There are few reports about the occurrence of pigments taking part in photoperiodic induction. If any pigment takes part it is surely the phytochrome, though it is not known whether it makes up all or only a part of such pigments. I have begun studies on pigments in relation to the effects of light-light quality and quantity-on their occurrence. In preliminary experiments using monochromatic light from pure colored fluorescent lamps, light conditions inducing and inhibiting flower formation in which a relatively short time of irradiation of red and far-red lights just before the effective dark treatment have been found. This made experiments using spectral beams from a spectroirradiater (biological spectrograph) possible or much 
easier, because a very long spectral beam irradiation is too expensive. A paper reporting detailed results on the occurrence of the pigments responsible for photoperiodic induction by monochromatic light is in preparation.

In the present paper differences between the effects of spectral beams and monochromatic fluorescent lights on inducing photoperiodic sensitivity in Pharbitis nil, i.e. a much shorter irradiation or a smaller spectral beam energy in wavelength from the red region, as compared to red fluorescent light, can induce flower formation.

The significance of the purity or wavelength width of monochromatic light from a grating spectroirradiater has been reported by MATSUI $e t a l$. in the process for protochlorophyllide phototransformation in vivo.4) Flower formation in Pharbitis plants under monochromatic light conditions was reported by TAKIMOTO and IKEDA.5) In the present study a similar experiment made under purer monochromatic light conditions with a more strict distribution of wavelength and energy.

\section{MATERIAL AND METHODS}

The plant material. A typical shortday plant Pharbitis nil Chois, strain "Violet" was used for its following characters: Its cotyledons receive photoperiodic induction. ${ }^{6}$ It forms floral buds under complete dark conditions, but once light is received its flower formation requires effective short conditions $^{7)}$ and its photoperiodic sensitivity increases from zero at germination to a maximum degree 3 or 4 days after germination. $\left.{ }^{8}\right)$

To obtain uniform germination, seeds were germinated using the procedure previously reported.9) Seeds which had rooted for several millimeters were planted in vermicurite about $1.5 \mathrm{~cm}$ deep in two files of 5 seeds each, in plastic pots $15 \times 10 \times 15 \mathrm{~cm}$ deep. Plants were grown by irrigating them with $0.1 \%$ hyponex solution under continuous blue, green, red and far-red light conditions in incubators, as well as with continuous dark and white light conditions at about $25^{\circ} \mathrm{C}$. After 3 or 4 days, cotyledons of plants grown under continuous white light had completely expanded and had reached their most sensitive phase. All plants, except those grown under red light, were then subjected to red light irradiation of various durations followed by one $16 \mathrm{hr}$ dark treatment after which they were placed under continuous white light conditions for about 3 weeks. Lengths of hypocotyls and petiols were measured and the number of floral buds and nodes were examined under a binocular microscope.

In experiments on the inhibition of floral induction, plants grown under continuous red light were exposed to far-red light of various durations just before the $16 \mathrm{hr}$ dark treatment.

To irradiate plants with spectral beams from a grating spectroirradiater, the plastic pots were arranged on an irradiation stage after growing the plants under continuous green light for 3 or 4 days, during which each file with 5 plants was subjected to a separate beam of a particular wavelength. Wavelengths of the beams irradiated to each file was marked, after removing the pots, as previously reported. ${ }^{10}$ ) All operations before and after spectrum irradiation were performed under dim green light.

Temperature for the growth and phototreatments, in principle, was $25^{\circ} \mathrm{C}$, except $23 \pm 1^{\circ} \mathrm{C}$ under white light, but the actual temperature of each light condition differed somewhat due to the colored light sources.

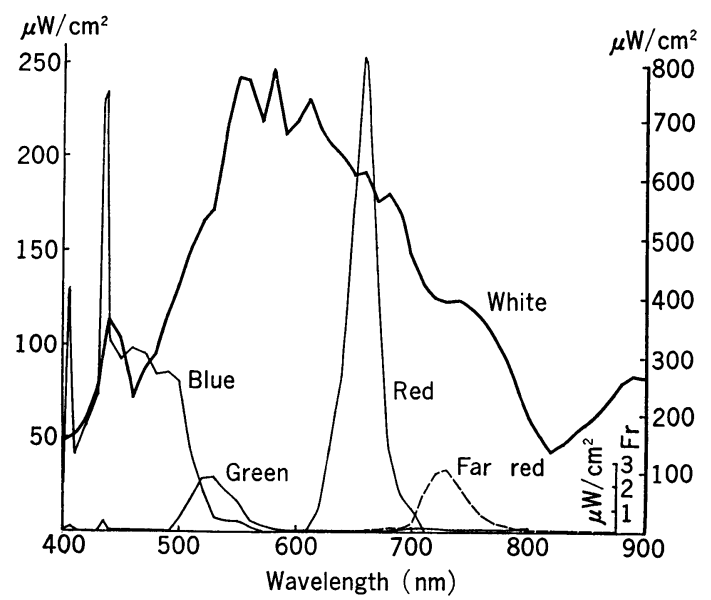

Fig. 1 Wavelength distribution for the lights used. Measured by Iio's spectroradiometer at distances of $100 \mathrm{~cm}$ in White, $20 \mathrm{~cm}$ in Blue, Green, Red and Far-red from lamps. 
Table 1 Distribution of light intensities in lux (in $\mathrm{kerg} / \mathrm{cm}^{2} / \mathrm{sec}$ ) in the incubators illuminated by red, blue, green and far-red light.

\begin{tabular}{|c|c|c|c|c|c|c|c|}
\hline \multirow[b]{2}{*}{$\begin{array}{l}\text { Location of } \\
\text { measurement* }\end{array}$} & \multicolumn{2}{|c|}{ Blue } & \multicolumn{2}{|c|}{ Green } & \multicolumn{2}{|c|}{ Red } & \multirow{2}{*}{$\frac{\text { Far-red }}{\text { Base }}$} \\
\hline & $\begin{array}{c}\text { Middle } \\
\text { (ca.25 cm } \\
\text { below } \\
\text { lamps) } \\
\end{array}$ & $\begin{array}{c}\text { Base } \\
\text { (ca. } 40 \mathrm{~cm} \\
\text { below } \\
\text { lamps) } \\
\end{array}$ & Middle & Base & Middle & Base & \\
\hline A & 280 & $250(6.3)$ & 360 & $280(9.7)$ & 410 & $360(4.2)$ & $(5.6)$ \\
\hline B & 340 & $260(6.6)$ & 360 & $280(9.0)$ & 370 & $340(4.2)$ & $(4.2)$ \\
\hline $\mathrm{C}$ & 430 & $360(8.3)$ & 520 & $360(10.1)$ & 680 & $460(5.2)$ & $(9.0)$ \\
\hline $\mathrm{D}$ & 275 & $240(6.0)$ & 300 & $230(8.5)$ & 410 & $350(4.4)$ & $(4.8)$ \\
\hline $\mathrm{E}$ & 345 & $250(6.3)$ & 280 & $240(8.8)$ & 340 & $310(3.5)$ & (3.8) \\
\hline
\end{tabular}

Light conditions. Blue, green, and red monochromatic lights were illuminated through 2 plates of the ceiling of incubators to the inside from eight $20 \mathrm{~W}$ pure colored fluorescent lamps (National). Far-red light was obtained by passing incandescent light from $100 \mathrm{~W}$ and $60 \mathrm{~W}$ lamps through an infrared filter IR-1 (NEC) and heat rays cut glass (Oota Glass Manuf. Co.). White light irradiation was done in an artificial light room furnished with eighteen $400 \mathrm{~W}$ metal halid lamps (Yōkō lamp, Toshiba) and twenty four 40W white fluorescent lamps (White $40 \mathrm{H}$ FLR W/A, Toshiba) in the ceiling which were isolated from the room with transparent plastic plates and separately air-conditioned. Illumination at plants level was about $15,000-25,000 \mathrm{~lx}$.

Distributions of the wavelengths of these light, measured with a spectroradiometer (Model SRP, Iio Electric Co.), are shown in Fig. 1. Light intensity and illumination were measured with a compensated thermopile (Kipp \& Zonen, CA 1) and a lux-meter (Photocell illuminometer type SPI-5, Toshiba), respectively. Values for each incubator showed fluctuations due to location both vertically and horizontally as seen in Table 1 .

To change the intensity of the red fluorescent light, box-shaped black mosquito nets in one to four piles were used to cover the plastic pots. In this case, the thermopile was not very useful for measuring light intensity under the nets due to a warp in the real value from radiant heat reflected from the black nets.

Methods of making the intensity distribution

$46(82)$ of the spectrum uniform. Irradiation with purer monochromatic light was done with spectral beams from a grating spectroirradiater (JASCO, CRM-FB) using a short-arc xenon lamp $(6.5 \mathrm{~kW})$ as the light source, to determine the action spectrum. Purity of the monochromatic light flux, methods for measuring the intensity etc., as well as the structure of the biological spectrograph have been reported elsewhere. ${ }^{(10,11)}$ To simultaneously irradiate each specimen arranged on the stage with monochromatic light beams of the same intensity, a technique to make the intensity distribution of the spectrum on the irradiation stage uniform was devised. Strips of black cardboard, 2 to $20 \mathrm{~mm}$ wide, were arranged at adequate intervals on the front glass of the spectroirradiater to

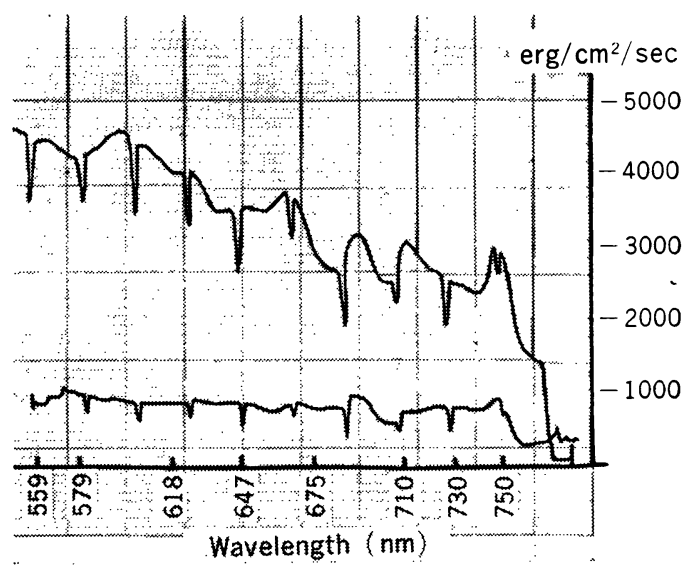

Fig.2 Energy distribution of original (upper) and uniformed spectrum in wavelength region used.

Environ. Control in Biol. (生物環境調節) 
Table 2 Effects of red light given before a $16 \mathrm{hr}$ dark period on flowering induction of Pharbitis seedlings.

\begin{tabular}{|c|c|c|c|c|}
\hline $\begin{array}{c}\text { Light } \\
\text { conditions } \\
\text { before } 16 \mathrm{hD}\end{array}$ & $\begin{array}{c}\text { No. of } \\
\text { plants } \\
\text { dissected }\end{array}$ & $\begin{array}{l}\% \text { of plants } \\
\text { with } \\
\text { flower buds }\end{array}$ & $\begin{array}{l}\text { No. of } \\
\text { flower buds } \\
\text { per plant }\end{array}$ & $\begin{array}{l}\% \text { of plants } \\
\text { with terminal } \\
\text { flower bud }\end{array}$ \\
\hline $\mathrm{D}$ & 8 & 0 & 0 & 0 \\
\hline $\mathrm{D}-1^{\mathrm{h}} \mathrm{R}$ & 9 & 0 & 0 & 0 \\
\hline $\mathrm{D}-2{ }^{\mathrm{h}} \mathrm{R}$ & 9 & 11.1 & 0.1 & 0 \\
\hline $\mathrm{D}-4^{\mathrm{h}} \mathrm{R}$ & 8 & 12.5 & 0.3 & 0 \\
\hline $\mathrm{D}-8^{\mathrm{h}} \mathrm{R}$ & 7 & 28.6 & 0.3 & 0 \\
\hline B & 10 & 0 & 0 & 0 \\
\hline $\mathrm{B}-1^{\mathrm{h}} \mathrm{R}$ & 10 & 20 & 0.3 & 0 \\
\hline $\mathrm{B}-2^{\mathrm{h}} \mathrm{R}$ & 10 & 10 & 0.2 & 0 \\
\hline$B-4^{h} R$ & 10 & 10 & 0.2 & 0 \\
\hline $\mathrm{B}-8^{\mathrm{h}} \mathrm{R}$ & 10 & 30 & 0.6 & 0 \\
\hline G & 10 & 10 & 0.1 & 0 \\
\hline $\mathrm{G}-1^{\mathrm{h}} \mathrm{R}$ & 10 & 40 & 0.6 & 0 \\
\hline $\mathrm{G}-2^{\mathrm{h}} \mathrm{R}$ & 8 & 62.5 & 1.4 & 0 \\
\hline $\mathrm{G}-4 \mathrm{~h} R$ & 9 & 77.8 & 1.6 & 0 \\
\hline $\mathrm{G}-8^{\mathrm{h}} \mathrm{R}$ & 9 & 100 & 3.0 & 10 \\
\hline FR & 5 & 0 & 0 & 0 \\
\hline $\mathrm{FR}-1 \mathrm{~h} \mathrm{R}$ & 8 & 25 & 0.4 & 0 \\
\hline $\mathrm{FR}-2{ }^{\mathrm{h}} \mathrm{R}$ & 6 & 50 & 1.3 & 0 \\
\hline $\mathrm{FR}-4 \mathrm{hR}$ & 9 & 55.6 & 1.4 & 11.1 \\
\hline $\mathrm{FR}-8^{\mathrm{h}} \mathrm{R}$ & 10 & 90 & 4.3 & 60 \\
\hline $\mathrm{R}$ & 10 & 100 & 5.6 & 100 \\
\hline $\mathrm{W}$ & 10 & 100 & 5.4 & 100 \\
\hline
\end{tabular}

B, G, R, FR, and D: blue, green, red, far-red light, and darkness, respectively.

shade the light beams on their path. The resultant distribution of light intensity is shown in Fig. 2. Uniform intensity was 825 $\mathrm{erg} / \mathrm{cm}^{2} / \mathrm{sec}$.

\section{RESULTS}

Floral induction by red light given just before a $16 \mathrm{hr}$ dark period

Among plants grown from germination under continuous monochromatic blue, green, red and far-red light, only plants grown under red light could always differentiated flower buds with one effective dark treatment, the rest were able to very seldom (see Table 2). But even plants grown under blue, green and far-red light, and in darkness induced flower formation when subjected to red light irradiation for adequate durations just before a $16 \mathrm{hr}$ dark period, as seen in Table 2. With an increase in the red light irradiation period, both the numbers of plants having flower buds and a terminal flower bud, and the number of flower buds per plant increased. As to the light conditions preceding red light, green and far-red lights induced the same 100 percent flowering as did continuous red or white light with an $8 \mathrm{hr}$ irradiation period; although far-red light by far induced many more terminal buds than did green light. As the energy of red light was 3690-4350 erg/ $\mathrm{cm}^{2} / \mathrm{sec}$, the minimum total energy of red light required to induce 100 percent flowering calculated from the data was $106 \times 10^{6}-125$ $\times 10^{6} \mathrm{erg} / \mathrm{cm}^{2}$. But the duration of the red light irradiation required for flowering induction tended to shift in every time period of the experiment, resulting in fluctuation of the total energy.

Relations between light intensity or illumina- 
Table 3 Effects of the intensity of red light given for $8 \mathrm{hr}$ before a $16 \mathrm{hr}$ dark period on the flowering response of Pharbitis seedlings.

\begin{tabular}{|c|c|c|c|c|c|}
\hline \multicolumn{2}{|c|}{ Red light intensity } & \multirow{2}{*}{$\begin{array}{l}\text { No. of } \\
\text { plants } \\
\text { dissected }\end{array}$} & \multirow{2}{*}{$\begin{array}{l}\% \text { of plants } \\
\text { with } \\
\text { flower buds }\end{array}$} & \multirow{2}{*}{$\begin{array}{l}\text { No. of } \\
\text { flower buds } \\
\text { per plant }\end{array}$} & \multirow{2}{*}{$\begin{array}{l}\% \text { of plants } \\
\text { with terminal } \\
\text { flower bud }\end{array}$} \\
\hline $\mathrm{erg} / \mathrm{cm}^{2} \cdot \mathrm{sec}$ & lux & & & & \\
\hline 3600 & 340 & 10 & 100 & 5.3 & 100 \\
\hline 2245 & 160 & 10 & 100 & 4.7 & 50 \\
\hline 1720 & 80 & 10 & 100 & 3.4 & 40 \\
\hline 1270 & 40 & 10 & 80 & 1.4 & 0 \\
\hline 980 & 30 & 10 & 0 & 0 & 0 \\
\hline
\end{tabular}

tion with red light and flower formation

In flowering induction by red light irradiation, both the total energy and the light intensity of illumination must be considered. Table 3 shows results of flowering induction in plants grown under continuous green light with $8 \mathrm{hrs}$ illumination of red light using varied intensities or illuminations given just before a $16 \mathrm{hr}$ dark period. The intensity was reduced by using black mosquito nets in piles of from one to four as previously described. With decreasing intensity, both the number of plants with flower buds and the number of flower buds per plant decreased to zero below $980 \mathrm{erg} / \mathrm{cm}^{2} / \mathrm{sec}$ or $30 \mathrm{~lx}$. Thus total energy of more than $28 \times 10^{6} \mathrm{erg} /$ $\mathrm{cm}^{2}$ for flower initiation and a value between $37 \times 10^{6}$ and $50 \times 10^{6} \mathrm{erg} / \mathrm{cm}^{2}$ for 100 percent flowering may be required.

\section{Flowering induction by spectral beams}

Plastic pots with plants grown under continuous green light were arranged on the irradiation stage so that 5 plants in a line would be parallel with the monochromatic light beams. Two cotyledons from each of 5 plants were arranged in a line. Then plants in lines were simultaneously irradiated with monochromatic light beams having wave length range of $\pm 3 \mathrm{~nm}$ of the same intensity, from about $500 \mathrm{~nm}$ to $700 \mathrm{~nm}$ for one, two and three hours. Results are shown in Fig. 3. The spectral regions effective for flowering induction are roughly the three regions with wavelengths of about $550-600$ $\mathrm{nm}, 620-640 \mathrm{~nm}$ and $650-675 \mathrm{~nm}$, though some shift in the regions was seen with irradiation times. The reasons for the shift may be that the positions arranged on the stage were not exactly the same in each

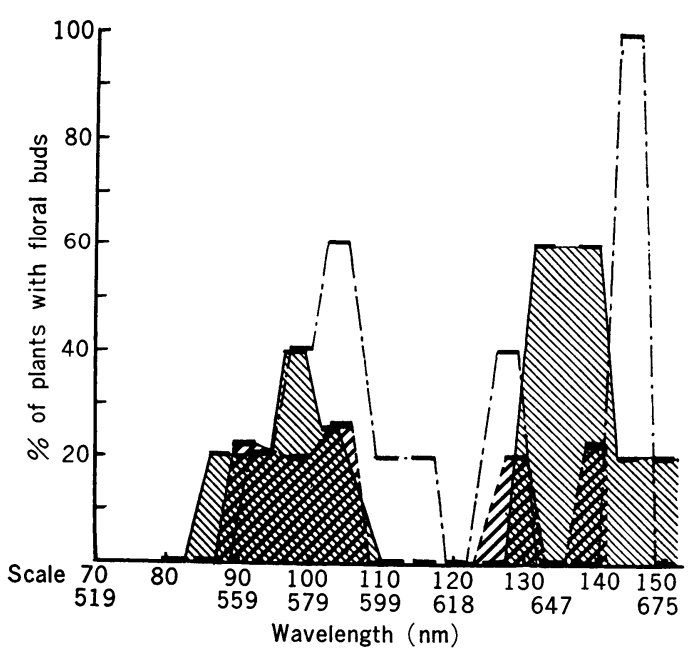

Fig. 3 Flowering induction by spectral light beams.

....... one hour irradiation, - two hours' irradiation, - - - three hours' irradiation. Short thick lines show location of plants wavelength regicns.

experiment, and that the wavelengths with which the cotyledons were irradiated also differed in width, of at $6 \mathrm{~nm}$, because cotyledons were about $3 \mathrm{~cm}$ wide. In the first and last regions the percent of plants with flower buds increased with irradiation times, from 20 to 60 and $100 \%$, respectively; whereas in the middle region of $620-640 \mathrm{~nm}$, they increased with irradiation for $2 \mathrm{hr}$ but decreased for $3 \mathrm{hr}$.

From the results, the total energies for flower initiation and for 100 percent flowering were calculated as about $3 \times 10^{6} \mathrm{erg} / \mathrm{cm}^{2}$ and $8.9 \times 10^{6} \mathrm{erg} / \mathrm{cm}^{2}$, respectively, which are very smaller in comparison to those for the preceding experiments using fluorescent

Environ. Control in Biol. (生物環境調節) 
Table 4 Effects of red light given just before a $16 \mathrm{hr}$ dark period on the flowering response of Pharbitis seedlings.

\begin{tabular}{ccccc}
\hline Treatment & $\begin{array}{c}\text { No. of } \\
\text { plants } \\
\text { dissected }\end{array}$ & $\begin{array}{c}\text { \% of plants } \\
\text { with } \\
\text { flower buds }\end{array}$ & $\begin{array}{c}\text { No. of } \\
\text { flower buds } \\
\text { per plant }\end{array}$ & $\begin{array}{c}\% \text { of plants } \\
\text { with terminal } \\
\text { flower bud }\end{array}$ \\
\hline $\mathrm{R}-10^{\prime} \mathrm{FR}-16^{\mathrm{h} D}$ & 13 & 30.8 & 0.5 & 0 \\
$\mathrm{R}-30^{\prime} \mathrm{FR}-16^{\mathrm{h} D}$ & 10 & 0 & 0 & 0 \\
$\mathrm{R}-1^{\mathrm{h}} \mathrm{FR}-16^{\mathrm{h}} \mathrm{D}$ & 10 & 0 & 0 & 0 \\
$\mathrm{R}-2^{\mathrm{h} F R}-16^{\mathrm{h}} \mathrm{D}$ & 10 & 0 & 0 & 0 \\
\hline
\end{tabular}

Table 5 Inhibitory effects of spectrum light beams on flowering induction of Pharbitis seedlings grown under continuous red light.

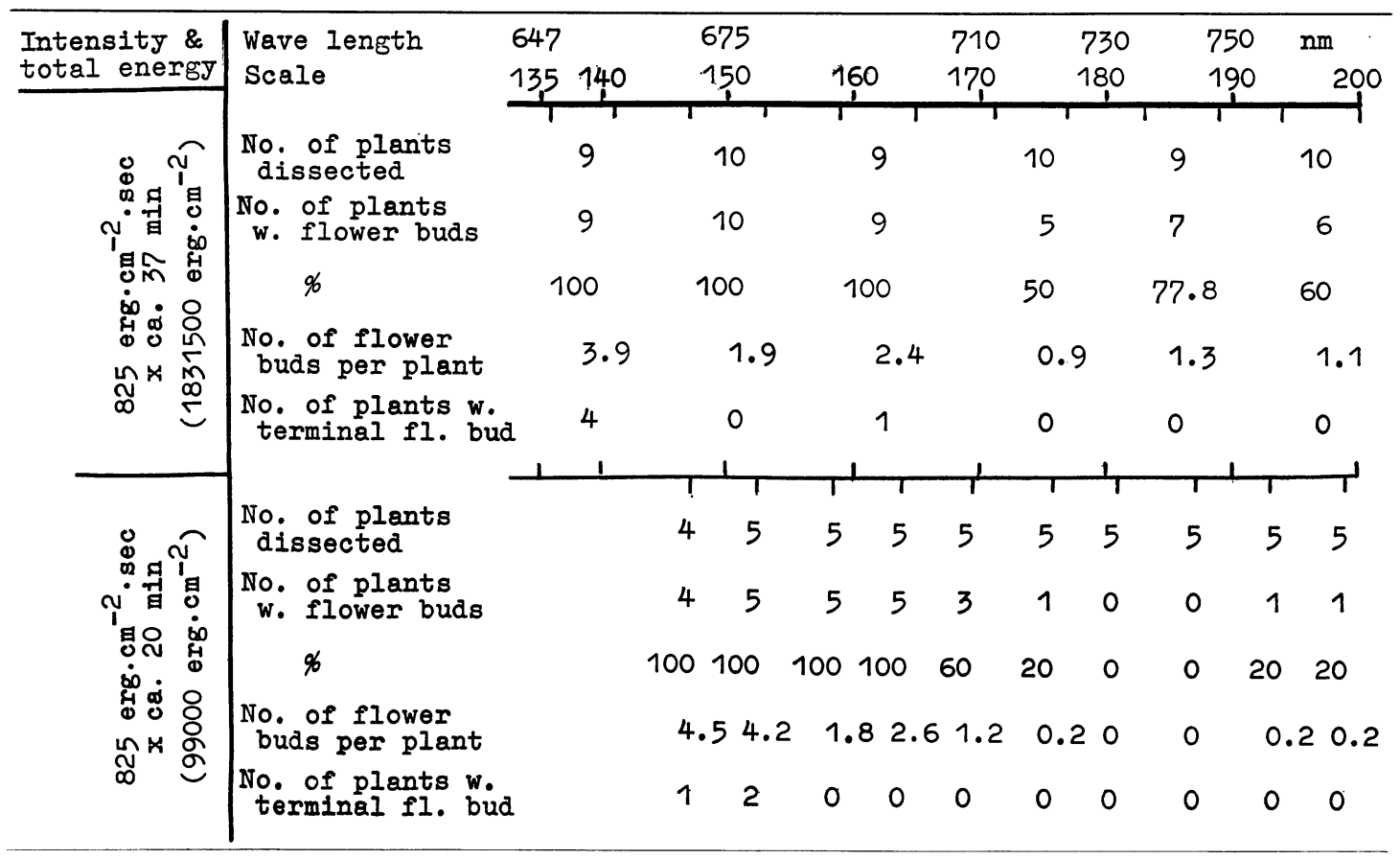

lights. In similar experiments giving short time irradiations for less than one hour, no flower formation occurred.

Inhibition of flowering induction by far-red light

Plants grown under continuous red light always induce almost 100 percent flowering with one $16 \mathrm{hr}$ dark period. When plants grown under continuous red light were irradiated with far-red light for $10 \mathrm{~min}$ to 2 $\mathrm{hr}$, flower formation was greatly inhibited. About $60 \%$ inhibition occurred with a 10 min irradiation and complete inhibition with only $30 \mathrm{~min}$ of irradiation (Table 4). The total energy for complete inhibition of flow- ering was determined to be about $8.6 \times 10^{6}$ $\mathrm{erg} / \mathrm{cm}^{2}$.

As seen in Table 5, results of experiments using spectral light from the red and farred regions with the same intensities indicate that the effective region for inhibition of flowering induction ranges from about 710 $\mathrm{nm}$ to $770 \mathrm{~nm}$. Complete inhibition of flowering induction was seen in a shorter irradiation for $20 \mathrm{~min}$, but in the $37 \mathrm{~min}$ irradiation. This contradiction will be discussed later. The result of the $20 \mathrm{~min}$ irradiation experiment showed that the total energy of the effective wavelength light beams for complete inhibition of flowering induction is nearly $99,000 \mathrm{erg} / \mathrm{cm}^{2}$. This 
value is also much lower than that calculated from the above results for far-red through an IR-1 filter from incandescent lamps.

\section{DISCUSSION}

In these experiments, all environmental conditions (i.e. light and temperature) except humidity, were controlled or measured as strictly as possible. The temperature of each incubator, taken with a thermometer protected from direct light, was adjusted to a constant $25^{\circ} \mathrm{C}$. But the temperature actually received by the plants was higher than $25^{\circ} \mathrm{C}$ due to radiant heat from the fluorescent lamps. This temperature differed considerably depending on the light quality or the color of the light. The highest radiant heat from the colored lights came from green probably due to high temperatures of the lamp tubes, themselves. Intensity values for fluorescent monochromatic lights, measured with a thermopile can not be said to be the real values because those values were also influenced by radiant heat. As the light intensity in an incubator changed, e.g. when the plant height was changed about $15 \mathrm{~cm}$, illumination intensity from green and red lights changed about 220 lux at the tip, so plants received a changing intensity while they were grown from germination to the time of the dark treatment. But with red or far-red light given before the dark period, a change in intensity was out of the question because of the short irradiation time.

Dark treatment was given simultaneously to all plants in the experimental lots, when they had grown under white light to their most sensitive phase. But it was not clear whether the sensitivity of plants grown under the other light conditions was higher or not. Because the growth states at the dark treatment, i.e. height, presence of the hook, the expansion rate and area of cotyledons, and degree of greening, differed depending on light conditions, these details will be reported elsewhere. The growth states of plants grown under red light, appeared to be similar to growth states under white light. Some plants grown, especially under green and far-red lights or in darkness occa- sionally whithered during the experiment, after their removal to white light conditions.

Photoperiodic sensitivity was apt to shift somewhat in each experimental period. This maybe due to the difference in growth state and accordingly the sensitivities of plants at the moment of dark treatment were not always uniform. Results shown in Table 5, in which a smaller total energy completely inhibited flowering induction, while a larger one in another experiment did not, may be explained by the preceding statements.

Thus, to decide the absolute value of the total energy which induces photoperiodic sensitivity or which inhibits photoperiodic induction is very difficult. Moreover, the measured value for light intensity does not always indicate the real value of pure light as stated. With the present techniques, a method for separately measuring light intensity and radiant heat was also very hard to find. Compared with light values from fluorescent lamps, the intensity values of spectral light beams must contain less radiant heat, because the light source lies at a greater distance. Therefore, values for the total energy required for the same photoresponse must inevitably be measured as larger values in colored fluorescent lights or filtered lights than in spectral beams. Thus, in the present experiment, a comparison of the total energies for fluorescent light and spectral light might not be a true one. The present experiment, however, indicates that the total energy required for a photoresponse is apt to be larger than the real value, which must be considered in photobiological experiments using monochromatic light other than spectral light beams.

Other causes for the difference in total energy values between the two kinds of light must exist, as the value of fluorescent light is much larger than that expected from the addition of radiant heat. The wavelength distribution in red fluorescent light ranges from about $610 \mathrm{~nm}$ to $710 \mathrm{~nm}$ (Fig. 1), corresponding to the spectrum light used, in which no inhibitory wavelength region is included. MATSUI and his colleagues reported that purer monochromatic light (narrower half-wavelength width light) in the effective region was very effective in the 
phototransformation of protochlorophyllide. So the difference may result from the greater effectiveness of irradiation with purer monochromatic spectral light which better induces photoperiodic sensitivity. The same is true for the inhibition of flowering induction by far-red light. Causes of differences in total energy values, however, are yet to clearly determined. Some possible causes are as follows: Since the limiting sensitivity. of the spectrophotometer used is roughly $10^{-5} \mathrm{erg} / \mathrm{cm}^{2} / \mathrm{sec}$, a stray flux of lower intensity may possibly be included in the fluorescent red light and the far-red light, which is not measurable by the photometer and some of which might possibly reduce the effectiveness of the main lights. The far-red light obtained from incandescent light through the filters possibly includes light from a wavelength region above 800 $\mathrm{nm}$, because the penetrating power of the radiant heat cut glass is $20.8 \%, 2.8 \%$, and $0.6 \%$ at $800 \mathrm{~nm}, 900 \mathrm{~nm}$ and $1,000 \mathrm{~nm}$, respectively. The action of light from a longer wavelength region is not known to be either promotive or inhibitory. The interaction, an oppositreaction among the constituent wavelength lights of the fluorescent monochromatic lights and far-red light used also might account for the differences.

Due to the possibility of broad and long term irradiation, and the ease in their use, monochromatic lights from colored fluorescent lamps or filtered from incandescent lamps are widely used in photo-biological expriments. The fact that the total energy values found in these experiments are apt to become larger than the real values must be considered for this type of experiment.

\section{REFERENCES}

(1) Takimoto, A. and Hamner, K. C. 1966 Timing mechanism determining the critical dark period in Pharbitis nil. Bot. Mag. Tokyo 79 : 484-485.

(2) HENDRICKs, S. B: 1960 Rates of change of phytochrome as an essential factor determining photoperiodism in plants. Cold Spring Harber Symp. on Quant. Biol. 25 : 245-248.

(3) Evans, L. T. 1971 Flower induction and the Florigen Consept. Ann. Review of Pl. Physiol. 22 : 365-394.

(4) Matsui, T. and AIGA, I. 1972 Biological studies on light quality in environment control III. Effect of wavelength width of irradiated monochromatic light on protochlorophyll phototransformation. Environ. Control in Biol. $10: 18-20$.

(5) TAKimoto, A. and IKEdA, K. 1959 Studies on the light controlling flower initiation of Pharbitis nil. I. Intensity and quality of the light preceding the inductive dark period. Bot. Mag. Tokyo $72: 137-145$.

(6) IMAMURA, Y. 1953 Photoperiodic initiation of flower primordia in Japanese morning glory. Phàrbitis nil Chois. Proc. Jap. Acad. 29 : 368 $-373$.

(7) Tashima, Y. and Imamura, S. 1953 Flower initiation in total darkness in Pharbitis nil Chois, a short day plant. Proc. Jap. Acad. 29 : 581-585.

(8) Marushige, K. and Marushige, Y. 1963 Photoperiodic sensitivity of Pharbitis nil seedlings of different ages in special reference to growth patterns. Bot. Mag. Tokyo 76 : 92-99.

(9) KonishI, M. 1964 Light-induced changes in phenolic inhibitors of indoleacetic acid oxidase in cotyledons of Pharbitis nil. Phytochem. $3: 559-568$.

(10) Konishi, M. 1970 A grating spectroirradiater and its use. Plant Physiol. 8 : 131-136 (in Japanese).

(11) KoNISHI, M. 1971 Grating spectro-irradiater for plants and some experimental instances: Effects of wavelengths on seed germination of Rumex obtusifolius and on hypocotyl lengthening of Pharbitis nil. Environ. Control in Biol. $8: 85-93$ (in Japanese with English summary). 
<和文抄録 $>$

\title{
アサガオの花成詩涭における光周感受性効果に対する波畏光と螢光灯
}

およびフィルターによる単色光との相建

\author{
小西 通 夫 \\ 京都大学農学部
}

1）アサガオ紫の光周感受性に関与する色素系に対する単色光の作用に関する予備実験の結果か ら, 16 時間暗期の直前に短時間赤色光を照射すると, 発芽時より青・緑・近赤外光および暗黒下 で生育した植物は常に花成誘導が起こる.これに対し，同様に照射した近赤外光は赤色光下で生育 した植物の花成誘導を阻害する. この事実は回析格子照射分光器からの波長光による実験を容易に した.

2）暗期直前に照射する赤色光の花成誘導に対する効果について，螢光灯（純単色）による赤色光 と照射分光器からの波長光 $(520 \sim 680 \mathrm{~nm})$ とを比較した.

3）花成誘導の阻害については，つねに花成誘導の起こる連続赤色光下で生育した植物に対し， 白熱灯を光源としてフィルターIR-1 と熱線吸収ガラスとを通して得た近赤外光と照射分光器によ る波長光 $(650 \sim 780 \mathrm{~nm})$ とを，暗期直前に短時間照射することによって比較した.

4） $100 \%$ 花成を誘導するのに必要な全エネルギー量は, 赤色蛨光灯では $37 \times 10^{6} \mathrm{erg} / \mathrm{cm}^{2}$, 波長 光では $8.9 \times 10^{6} \mathrm{erg} / \mathrm{cm}^{2}$ であった. 花成誘導の完全な阻害についてはフィルターによる近赤外光 は $8.6 \times 10^{6} \mathrm{erg} / \mathrm{cm}^{2}$ であり, 波長光は $9.9 \times 10^{4} \mathrm{erg} / \mathrm{cm}^{2}$ であった.

本実験で, 同じ効果を生じるのに必要な全エネルギー量は, 波長光以外の光において波長光より, あるいは真の值より大きな值を示し，この事実は波長光以外の単色光を用いる実験に際して留意す べきことを提示した.

5）花成誘導に有効な波長域はおおよそ $500 \sim 600 \mathrm{~nm}, 620 \sim 640 \mathrm{~nm}$ と $650 \sim 675 \mathrm{~nm}$ の 3 波長 域であり, 花成誘導の阻害は $710 \sim 770 \mathrm{~nm}$ の波長城である.

6）考察において光・温度などの実験条件について精細に検討し，唫光灯と波長光による全エネ ルギーに差のある理由について考察した. 